D.R. Biehl FrCP(C), J. Côté FRCP(C), J.G. Wade FRCP(C), G.A. Gregory MD, D. Sitar PH D

\title{
Uptake of Halothane by the Foetal Lamb in Utero
}

The uptake of halothane by the normal foetus in utero was determined, using the pregnant ewe as an experimental animal model. Six pregnant ewes of 125-135 days gestation were surgically prepared under general anaesthesia. Polyvinyl catheters were placed in the marernal femoral artery and vein and in the foetal' femoral artery and vein and the axillary artery. Each animal was allowed to recover for 24-36 hours prior to study. On the day of the experiment a tracheostomy was performed and after a control period, the ewe was anesthetized with 1.5 per cent hatothane in oxygen. During each study, maternal and foetal blood pressure were contintously recorded. Simultaneous maternal and foetal arterial halothane concentrations were measured to construct an uptake curve for the foetus. During the study. foetal mean arterial blood pressure fell significantly (27 per cent). There were no significant changes in foetal or maternal pulse rate or acidbase status. Halothane appeared in the foetal blood by two minutes but foetal halothane levels remained signifcantly lower than maternal for 24 minutes. We conclude that halothane crosses the placenia rapidly and produces a decrease in foetal blood pressure but no change in foetal oxygenation or acid-base status.

\section{Key Words}

ANAESTHETICS, VOLATILE: halothane, pharmakokinetics, foetus.

From the Department of Anesthesia, University of Manitoba.

Address correspondence io: Diane R. Biehl MD, Department of Anesthesia, University of Manitoba, St. Boniface General Hospital, 409 Taché Avenue, Winnipeg, Manitoba R2H 2 A6.
One of the main concerns of using general anaesthesia in obstetrical patients is the effect it may have on the foetus. ${ }^{1,2}$ Several of the general anaesthetic agents have been shown to cross the placenta rapidly $y^{3}$ and prolonged general anaesthesia in the mother results in depression of Apgar scores in the infant. ${ }^{4}$ Certain situations in obstetrics, however, necessitate the use of general anaesthesia. Caesarean Sections where the mother refuses regional anaesthesia, or where regional is contra-indicated, are two examples.

To provide optimum anaesthesia for the mother and avoid depression in the newbom, the placental transfer of anaesthetic agents needs to be understood in more detail. As a first step in this undertaking we have studied the uptake of halothane by the foetus using the pregnant ewe as an animal model.

\section{Methad}

Six pregnant ewes of 125-135 days gestation (term 150 days) were surgically prepared as follows: under halothane in oxygen anaesthesia with controlled ventilation, polyvinyl catheters were placed in the maternal femoral artery and vein. Through a midline incision the uterus was exposed and a smal] hysterotomy incision was made. A foetal limb was withdrawn and polyvinyl catheters were placed in the femoral artery and vein and the axillary artery. All incisions were closed and the catheters tunnelled subcutaneously to the maternal flank and enclosed in a protective pocket. Each animal was allowed to recover for 24-36 hours prior to a study.

On the day of the study a tracheostomy was performed in the ewe under local anaesthesia. Maternal and foetal mean arterial blood pressure and pulse rate were recorded continuously via the femoral arterial catheters on a Hewlett-Packard multi-channel recorder. Maternal and foetal arterial 
TABLE 1 Maternal and Foetal Mean Arterial Blood Pressure (MABP) and Pulse Rate Charges expressed as Per Cent Change from Control During Halothane Anaesthesia (1.5 Per Cent Inspired Cancentration). $(\mathbf{N}=6 ;$ Mean \pm S.D. $)$

\begin{tabular}{|c|c|c|c|c|c|c|}
\hline & \multirow[b]{2}{*}{ Control } & \multicolumn{5}{|c|}{ Time (minutes) } \\
\hline & & 8 & 16 & 32 & 64 & 96 \\
\hline Maternal & & 5 & $\%$ & $\%$ & $\%$ & $\%$ \\
\hline MABP & 81.3 & -9.2 & -24.7 & -16.8 & -10.0 & -2.4 \\
\hline (Torr) & \pm 13.2 & \pm 10.3 & \pm 12.5 & \pm 15.4 & $\pm 19,4$ & \pm 20.3 \\
\hline $\begin{array}{l}\text { Pulse Rate } \\
\text { (bents/min) }\end{array}$ & $\begin{array}{r}84.5 \\
\pm 9.6\end{array}$ & $\begin{array}{l}+18.8 \\
\pm 20.6\end{array}$ & $\begin{array}{l}+0.8 \\
\pm 5.2\end{array}$ & $\begin{array}{l}-0.9 \\
\pm 5.2\end{array}$ & $\begin{array}{r}+2.9 \\
\pm 26.5\end{array}$ & $\begin{array}{r}+9.3 \\
\pm 31.4\end{array}$ \\
\hline \multicolumn{7}{|l|}{ Foera! } \\
\hline MAB]P & 52.3 & $-27.1^{*}$ & $-29.2^{*}$ & $-33.0^{*}$ & $-30.7^{*}$ & $-33.9 *$ \\
\hline (Torr) & \pm 7.84 & \pm 7.8 & \pm 6.4 & \pm 10.3 & \pm 8.82 & \pm 6.9 \\
\hline Pulse Rate & 160.0 & +4.1 & +4.1 & +6.4 & -8.2 & -4.2 \\
\hline (beiats/min) & \pm 7.35 & \pm 7.8 & \pm 22.8 & \pm 22.0 & \pm 9.3 & \pm 7.1 \\
\hline
\end{tabular}

TABI.E Il Matemal and Foetal Blood Gases and pH Expressed as Absolute Change from Control During Halothane Anaesthesia (1.5 Per Cent Inspired Concentration) $(\mathrm{N}=6$; Mean \pm S.D.)

\begin{tabular}{|c|c|c|c|c|c|c|}
\hline & \multirow[b]{2}{*}{ Conrral } & \multicolumn{5}{|c|}{ Time (minutes) } \\
\hline & & 8 & 16 & 32 & 64 & 96 \\
\hline $\begin{array}{l}\text { Maternal } \\
\mathrm{pO}_{2} \text { (Torr) }\end{array}$ & $\begin{array}{c}414 \\
\pm 25.7\end{array}$ & $\begin{array}{l}426 \\
\pm 9.6\end{array}$ & $\begin{array}{l}409 \\
\pm 73.9\end{array}$ & $\begin{array}{l}403 \\
=75.9\end{array}$ & $\begin{array}{l}411 \\
\pm 31.9\end{array}$ & $\begin{array}{l}403 \\
\pm 32.6\end{array}$ \\
\hline $\mathrm{pCO}_{2}$ (Tarr) & $\begin{array}{r}28.1 \\
\pm 6.4\end{array}$ & $\begin{array}{r}27.2 \\
\pm 3.4\end{array}$ & $\begin{array}{r}21.6 \\
\pm 6.1\end{array}$ & $\begin{array}{r}21.1 \\
\pm 5.9\end{array}$ & $\begin{array}{r}26.4 \\
\pm 9.8\end{array}$ & $\begin{array}{r}28.4 \\
\pm 5.9\end{array}$ \\
\hline pH (Linits) & $\begin{array}{r}7.50 \\
\pm 0.10\end{array}$ & $\begin{array}{r}7.51 \\
\pm 0.05\end{array}$ & $\begin{array}{r}7.54 \\
\pm 0.20\end{array}$ & $\begin{array}{r}7.60 \\
\pm 0.12\end{array}$ & $\begin{array}{r}7.53 \\
\pm 0.05\end{array}$ & $\begin{array}{r}7.48 \\
\pm 0.07\end{array}$ \\
\hline $\mathrm{H}^{+}$nenomoles $/ \mathrm{L}$ & $\begin{array}{l}31.6 \\
\pm 0.79\end{array}$ & $\begin{array}{l}30.9 \\
\pm 0.89\end{array}$ & $\begin{array}{c}34.6 \\
\pm 0.63\end{array}$ & $\begin{array}{l}25.1 \\
\pm 0.76\end{array}$ & $\begin{array}{l}29.5 \\
\pm 0.89\end{array}$ & $\begin{array}{l}33.1 \\
\pm 0.85\end{array}$ \\
\hline B.E. & $\begin{array}{l}-1.1 \\
\pm 2.9\end{array}$ & $\begin{array}{l}+0.3 \\
\pm 2.5\end{array}$ & $\begin{array}{l}+0.6 \\
\pm 1.2\end{array}$ & $\begin{array}{l}+1.8 \\
\pm 2.5\end{array}$ & $\begin{array}{l}+0.8 \\
\pm 2.9\end{array}$ & $\begin{array}{l}+1.0 \\
\pm 2.7\end{array}$ \\
\hline \multicolumn{7}{|l|}{ Foetel } \\
\hline $\mathrm{pO}_{2}$ (Forr) & $\begin{array}{r}22.0 \\
\pm 4.2\end{array}$ & $\begin{array}{r}21.6 \\
\pm 3.4\end{array}$ & $\begin{array}{r}21.6 \\
\pm 2.9\end{array}$ & $\begin{array}{r}17.7 \\
\pm 2.7\end{array}$ & $\begin{array}{r}20.5 \\
\pm 3.4\end{array}$ & $\begin{array}{r}21.7 \\
\pm 5.4\end{array}$ \\
\hline $\mathrm{pCO}_{2}$ (Torr) & $\begin{array}{r}44.1 \\
\pm 5.8\end{array}$ & $\begin{array}{r}45.2 \\
\pm 8.8\end{array}$ & $\begin{array}{r}40.7 \\
\pm 6.6\end{array}$ & $\begin{array}{r}39.6 \\
\pm 4.9\end{array}$ & $\begin{array}{l}41.7 \\
\pm 8.8\end{array}$ & $\begin{array}{r}50.6 \\
\pm 13.2\end{array}$ \\
\hline pH (Units) & $\begin{array}{r}7.29 \\
\pm 0.04\end{array}$ & $\begin{array}{r}7.31 \\
\pm 0.06\end{array}$ & $\begin{array}{r}7.33 \\
\pm 0.06\end{array}$ & $\begin{array}{r}7.37 \\
\pm 0.04\end{array}$ & $\begin{array}{r}7.34 \\
\pm 0.12\end{array}$ & $\begin{array}{r}7.27 \\
\pm 0.12\end{array}$ \\
\hline $\mathrm{H}^{+}$nemomolesil & $\begin{array}{c}51.2 \\
\pm 0.91\end{array}$ & $\begin{array}{l}48.9 \\
\pm 0.87\end{array}$ & $\begin{array}{l}46.7 \\
\pm 0.87\end{array}$ & $\begin{array}{l}42.6 \\
\pm 0.91\end{array}$ & $\begin{array}{l}45.7 \\
\pm 0.76\end{array}$ & $\begin{array}{l}53.7 \\
\pm 0.76\end{array}$ \\
\hline B.E. & $\begin{array}{l}-4.3 \\
\pm 3.4\end{array}$ & $\begin{array}{l}-3.7 \\
\pm 3.8\end{array}$ & $\begin{array}{l}-0.6 \\
\pm 8.3\end{array}$ & $\begin{array}{l}-0.8 \\
\pm 2.4\end{array}$ & $\begin{array}{l}-1.7 \\
\pm 2.9\end{array}$ & $\begin{array}{l}-4.4 \\
\pm 6.4\end{array}$ \\
\hline
\end{tabular}

blood gases and $\mathrm{pH}$ were measured every 15 halothane, at a constant inspired concentration of minutes on a Corning blood gas analyser.

1.5 per cent, was introduced into the maternal

Each study began with a 30 -minute control breathing circuit. The inspired concentration was period with the ewe breathing 100 per cent oxygen. monitored on a Beckman infrared analyser.

This insured stability of the preparation. Then

Maternal and foetal arterial concentration of 
TABLE III Maternal and Foetal Halothane Levels During Administration of Halothane at a Fixed Inspired Concentration of $1.5 \operatorname{Per} \operatorname{Cent}(\mathrm{N}=6 ;$ Mean \pm S.D. $)$

\begin{tabular}{|c|c|c|c|c|c|c|c|c|c|c|}
\hline & \multicolumn{9}{|l|}{ Time } & \multirow[b]{2}{*}{$96 \mathrm{~min}$} \\
\hline & $0 \mathrm{~min}$ & $2 \mathrm{~min}$ & $4 \min$ & $8 \min$ & $16 \min$ & $24 \min$ & $32 \mathrm{~min}$ & $48 \min$ & $64 \min$ & \\
\hline \multirow{2}{*}{$\begin{array}{l}\text { Matemal arterial } \\
\text { concentration } \mathrm{Mg} / \mathrm{L}\end{array}$} & 0 & 43.4 & 53.0 & 92.0 & 119.7 & 125.2 & 141.6 & 162.7 & 162.8 & 168.2 \\
\hline & & \pm 18.0 & \pm 13.8 & \pm 40.5 & \pm 40.5 & \pm 27.8 & \pm 60.5 & \pm 69.5 & \pm 62.2 & \pm 64.5 \\
\hline Foetal concentration & 0 & $13.8^{*}$ & $20.2^{*}$ & $35.5^{*}$ & 64.3* & $80.0^{*}$ & 88.4 & 104.5 & 121.4 & 111.2 \\
\hline Mg/L & & \pm 6.5 & \pm 6.8 & \pm 10.2 & \pm 11.8 & \pm 19.5 & \pm 18.5 & \pm 24.7 & \pm 34.5 & \pm 25.3 \\
\hline
\end{tabular}

${ }^{*} \mathrm{p}<0.05$

halothane were measured at $2,4,8,16,32,48,64$, and 96 minutes of anaesthesia. Maternal samples were drawn from the femoral artery and foetal samples from the axillary artery. The samples were analysed by gas chromatography. ${ }^{5}$

The data for mean arterial blood pressure, pulse rate, $\mathrm{pH}$, and blood gases were analysed by oneway analysis of variance. The unpaired $t$ test was used for maternal and foetal arterial hatothane concentrations. A p value of less than 0.5 was considered significant. ${ }^{6}$

\section{Results}

Maternal mean arterial blood pressure (MABP) (Table I) tended to decline during the first 24 minutes of the study but the values were not significantly different from control. There was no significant change in pulse rate. Foetal MABP fell significantly, by 27 per cent after eight minutes of halothane anaesthesia and remained decreased throughout the remainder of the study. There was no significant change in pulse rate.

Maternal and foetal blood gases and $\mathrm{pH}$ are shown in Table II. There were no significant changes in any of these parameters during the study.

Matemal and foetal arterial halothane concentrations expressed as $\mathrm{mg} / \mathrm{L}$ are shown in Table II, and graphically as vol.\% in Figure 1. Halothane was present in the foetal blood by two minutes but the concentration was significantly lower than matemal for 24 minutes. By 32 minutes, although mean foetal arterial concentrations were lower than maternal, there was no statistically significant difference.

\section{Discussion}

Despite a significant fall in foetal MABP during the study, foetal oxygenation and acid-base status

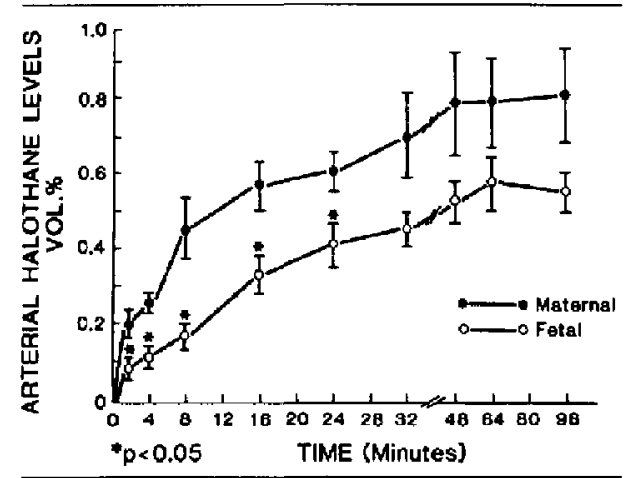

FIGURE I Matemal and foetal arterial halothane levels during administration of halothane at an inspired coneentration of 1.5 per cent for 96 minutes $(N=6$; Mean \pm S.E.)

remained unchanged from the control values. The normal foetal lamb appears to tolerate halothane anaesthesia well.

Halothane rapidly crosses the placenta but equilibrium with the maternal arterial concentrations is not reached until after 24 minutes of anaesthesia. There are several possible explanations for the delay in reaching equilibrium.

First, shunting of blood on both the maternal and foetal sides of the placenta might result in lower foetal concentrations of halothane. This could be considered analogous to $\mathrm{V} / \mathrm{Q}$ abnormalities in the lung.

Second, the placenta is a very active metabolic organ and uptake of halothane may be considerable. The trophoblastic cells interposed between maternal and foetal blood may act as a large reservoir for halothane.

Third, the measurement of the foetal arterial concentration was from the axillary artery to reflect 
levels of halothane going to the foetal brain. Foetal blood coming from the placenta via the umbilical vein traverses the liver prior to entering the arterial system. Uptake of halothane by foetal liver in guinea pigs ${ }^{7}$ has been shown to be extremely high. Uptake by the liver may, in part, account for the lower arterial levels which we found in the arterial blood of the foetal lamb.

Despite the time delay in reaching equilibrium between maternal and foetal arterial halothane concentrations, the foetus is affected by even low levels of halothane. The fall in foetal MABP was significant by eight minutes. This did not impair oxygenation or acid-base status in the normal foetal lamb but this degree of hypotension in a stressed foetus might have deleterious effects. The effects of halothane on the stressed foetus are currently being examined in our laboratory.

\section{Conclusion}

In the normal foetal lamb in utero, low levels of halothane produce a significant fall in MABP but no change in pulse rate, oxygenation, or acid-base status. Halothane appears in the foetal circulation within two minutes but equilibrium is not reached until after 24 minutes of halothane anaesthesia.

\section{Acknowledgments}

We gratefully acknowledge the technical assistance of Miss Maureen Cumming and Mr. Wayne Pucci, and the typing of the manuscript by Mrs. Beverley Fewster

\section{References}

1 Latta IP, Waldron BA. Anesthesia for caesarean section. Br J Anaesth 1977; 49: 371-8.

2 Moir DD. Anesthesia for caesarean section: An evaluation of a method using low concentrations of halothane and 50 per cent of oxygen. Br J Anaesth 1970; 42: 136-142.

3 Marx GF. Placental transfer of anesthetic agents. Anesthesia Rounds, Vol. IV, No. 3, Ayerst Laboratories, pp 8-23, 1973.

4 Rolbin SH, Levinson G, Shnider SM. Current status of amesthesia for cesarean section. Weckly Ancsthesiology Update, Vol. 1, Lesson 7, Weekly Anesthesiology Update, Inc., Princeton, N.J., 1977.

5 Davies $D D$. A method of gas chromatography using electron-capture detection for the determination of blood concentrations of halothane, chloroform, trichloroethylene. Br J Anaesth 1978; 50: 147-155.

6 Zar JH. One-sample hypothesis. Chapter 8 in Biostatistical Analysis, Prentice-Hall, Inc., N.J., 1974.

7 Geddes IC, Brand L, Finster M, et at. Distribution of Halothane ${ }^{\mathrm{t2}} \mathrm{Br}$ in maternal and fetal guinea pig tissues. Br J Anaesth. 1972; 44: 542-547.

\section{Résumé}

La résorption d" halotane chez le fatus normal in utero a éte mise en évidence avec notre expérience chez la brebis gravide. Six brebis gravides de 125-135 jours en gestation ont été préparées pour l'opération chirurgicale avec l'anesthésie générale. On a placé des cathéters dans l'artère et la veine fémorales maternelles ainsi que dans l'artère fémorale du foetus et l'artère axillaire. Chaque brebis pouvait récupérer de 24 a 36 heures avant notre expérience. Le jour de l' expérience, on effectua une trachétomie et après la période de contrôle, la brebis fut anesthésiée avec 1.5 pour cent d'halotune contenu dans l'oxygène. Pendant la durée de notre étude, la tension artérielle maternelle et celle du frotus furent mesurées continuellement. Les concentrations simultanées d' halotane du débit artériel maternel nel et fotal ont été mesurés afin d' obtenir une courbe de résorption du fattes. Durant le cours de notre expérience, la tension artérielle moyenne du fatus baissa de façon signiffcative (27 pour cent). Il n'y a pas eu de changements significatifs de la fréquence du pouls chez la brebis er le fatus ni de l'équilibre acido-basique. L'halotane passe dans le sang fotal en deux minutes mais le niveau d'halotane reste significativement plus bas que celui de la brebis. Nous concluons donc que I' halotane passe rapidement dans le placenta et engendre une baisse de la tension artérielle du fatus. Cependant, on n'observe pas de changements darts l'oxygénation du faetus ni de l'équilibre acido-basique. 